\title{
The effectiveness of silvofishery system in water treatment in intensive whiteleg shrimp (Litopenaeus vannamei) ponds, Probolinggo District, East Java, Indonesia
}

\author{
MUHAMMAD MUSA ${ }^{1,2, \bullet}$, EVELLIN DEWI LUSIANA $^{1,2}$, NANIK RETNO BUWONO $^{1,2}$, SULASTRI ARSAD $^{1,2}$, \\ MOHAMMAD MAHMUDI ${ }^{1,2}$ \\ ${ }^{1}$ Department of Aquatic Resource Management, Faculty of Fisheries and Marine Science, Universitas Brawijaya. J1. Veteran, Malang 65145, East Java, \\ Indonesia. Tel./fax.: +62-341-553512, `email: musa_fpi@ub.ac.id \\ ${ }^{2}$ AquaRES Research Group, Faculty of Fisheries and Marine Science, Universitas Brawijaya. Jl. Veteran, Malang 65145, East Java, Indonesia
}

Manuscript received: 13 July 2020. Revision accepted: 21 September 2020.

\begin{abstract}
Musa M, Lusiana ED, Buwono NR, Arsad S, Mahmudi M. 2020. The effectiveness of silvofishery system in water treatment in intensive whiteleg shrimp (Litopenaeus vannamei) ponds, Probolinggo District, East Java Indonesia. Biodiversitas 21: 4695-4701. Whiteleg shrimp (Litopenaeus vannamei) is a popular aquaculture species in Indonesia due to its high market demand. It requires excellent water quality to ensure its growth rate and production. Therefore, intensive culture system is considered. However, the system threatens the sustainability of the adjacent environment and thus proper water treatment is necessary to increase the quality of water used in shrimp farming as well as the wastewater it produces. In this study, we explored the use of a silvofishery system that integrates mangroves into a pond as a potential solution to this issue. This study aimed to assess the effectiveness of the silvofishery system at treating water inputs and effluents of a whiteleg shrimp pond in Probolinggo District, East Java, Indonesia. Eight physicochemical water quality parameters and a phytoplankton community at four sampling sites during neap tide period were examined in this study. The effectiveness of the silvofishery system in increasing water quality was analyzed using analysis of variance (ANOVA), while the diversity of phytoplankton for biomonitoring was measured with the Shannon-Wiener diversity index (H'). The results showed that the mangrove effectively increased the quality of the water supply and wastewater in the intensive whiteleg shrimp pond-especially in terms of nutrient removal-as well as the biodiversity of its phytoplankton community. Other parameters such as TOM and ammonia also decreased, though this was not statistically proven.
\end{abstract}

Keywords: Intensive pond, silvofishery system, water treatment, whiteleg shrimp

\section{INTRODUCTION}

Whiteleg shrimp (Litopenaeus vannamei) is a prime aquaculture commodity in Indonesia and a major contributor to export earnings along with oil and gas (Sitompul et al. 2018). Compared to other aquaculture biotas, whiteleg shrimp have numerous advantages, such as high market demand, short culture period, high growth rate, and high tolerance to environmental changes (Thakur et al. 2018; Venkateswarlu et al. 2019). However, the success of whiteleg shrimp cultivation still depends heavily on water quality (Nguyen et al. 2019). Water quality plays an important role in increasing the productivity of the pond, and high-quality water provides a balanced and healthy environment for cultured biotas (Ferreira et al. 2011). Moreover, proper water quality management serves to reduce stresses on shrimp that can expose them to various diseases (Samadan et al. 2018). However, water supplies for whiteleg shrimp cultivation are prone to pollution from uncontrolled waste from various anthropogenic activities (Nguyen and Ford 2010). Therefore, the water supply needs to be treated to meet shrimp farming standards (Setiadi and Setijaningsih 2011).

There are three types of culture systems-traditional, semi-intensive, and intensive-that can be used for whiteleg shrimp cultivation (Krummenauer et al. 2011). The differences between these methods lie in several aspects, including the type of pond, size of the pond, size of the venture capital, stocking density, type of feed, water management, and applied technology (López 2011). A traditional cultivation system is the simplest type of system and is characterized by low stocking densities, natural food feeding, relatively small business capital, and cultivation activities that are more dependent on natural conditions (Anras et al. 2010). Semi-intensive and intensive methods are characterized by high stocking densities, a combination of natural and artificial feeds, the presence of periodic water quality measurements, and greater business capital (Oddsson 2020). In response to the high demand for whiteleg shrimp, many farmers have implemented intensive systems because they can significantly increase shrimp production (Nguyen et al. 2020).

The application of an intensive system in aquaculture can threaten the sustainability of the adjacent environment and the business itself (Na-nakorn et al. 2017). Effluents from an intensive pond are rich in organic materials and chemical compounds as a result of artificial feed usage and shrimp defecation, which can potentially pollute adjacent bodies of water (Barraza-Guardado et al. 2013), increase nutrient enrichment in the water, and trigger algal blooms 
that are harmful to other aquatic organisms (Herbeck et al. 2013). A silvofishery system can be used to treat water in an intensive pond. This system integrates a pond with mangrove trees in order to produce economic benefits from aquaculture activities and environmental sustainability (Sari et al. 2014). The presence of mangroves in the pond area is expected to improve water quality because mangroves can absorb organic materials resulting from anthropogenic activities (De-León-Herrera et al. 2015). Many reports have demonstrated the uptake of these materials by mangrove trees. Microbial activity in the mangrove sediments also plays a major role in removing organic matter and nutrients from wastewater (Ouyang and Guo 2016; Tian et al. 2018).

This study aims to assess the effectiveness of silvofishery systems in increasing the quality of water used in shrimp farming as well as the wastewater it produces. While the use of mangroves in wastewater treatment is common, their ability to improve water inputs for aquaculture has been less frequently investigated. Thus, this research could potentially double the known benefits of silvofishery systems.

\section{MATERIALS AND METHODS}

\section{Study area}

This research was conducted at whiteleg shrimp ponds in the Brackish and Marine Water Laboratory of Brawijaya University, that located in the coastal zone of Probolinggo District, East Java Indonesia and is surrounded by mangrove forests (Figure 1). The silvofishery system was applied to the aquaculture process for water treatment.
Four sampling sites were used in this study (Figure 1). Site 1 is a water inlet from the river to the mangroves, while Site 2 is a water inlet from the mangroves to the pond. Site 3 is a water outlet from the pond to the mangroves, which contains waste materials, and Site 4 is a water outlet from the mangroves to the river and adjacent water.

The tidal type in Probolinggo coastal waters is mixed tide prevailing semidiurnal. Sampling was thus conducted during neap tide from September to November 2018, as in this period the water movements are relatively constant. Researchers sampled these waters every two weeks for a total of seven replications.

\section{Sample collection}

At each sampling site, we observed the following water quality parameters: temperature $\left({ }^{0} \mathrm{C}\right), \mathrm{pH}$, salinity $\left(\%{ }^{0}\right)$, dissolved oxygen (DO, in mg. $\mathrm{L}^{-1}$ unit), nitrate (mg. $\mathrm{L}^{-1}$ ), orthophosphate $\left(\mathrm{mg} . \mathrm{L}^{-1}\right)$, and ammonia $\left(\mathrm{mg} . \mathrm{L}^{-1}\right)$. These parameters were measured in situ using a thermometer (temperature), $\mathrm{pH}$ meter $(\mathrm{pH})$, refractometer (salinity), DOmeter (DO), and test kits (nitrate, orthophosphate, and ammonia). Water samples for ex-situ observation was done using plankton net size with pore size of $30 \mu \mathrm{m}$. Then, they were filtered into bottles (volume $30 \mathrm{ml}$ ) and added with 23 drops of $4 \%$ formalin. Phytoplankton abundance was calculated by using Lackey's drop approach, while the identification of this biota was based on Prescott's book on algae identification (Jannah et al. 2012) and the World Register of Marine Species (http://www.marinespecies.org) (Mahmudi et al. 2020).
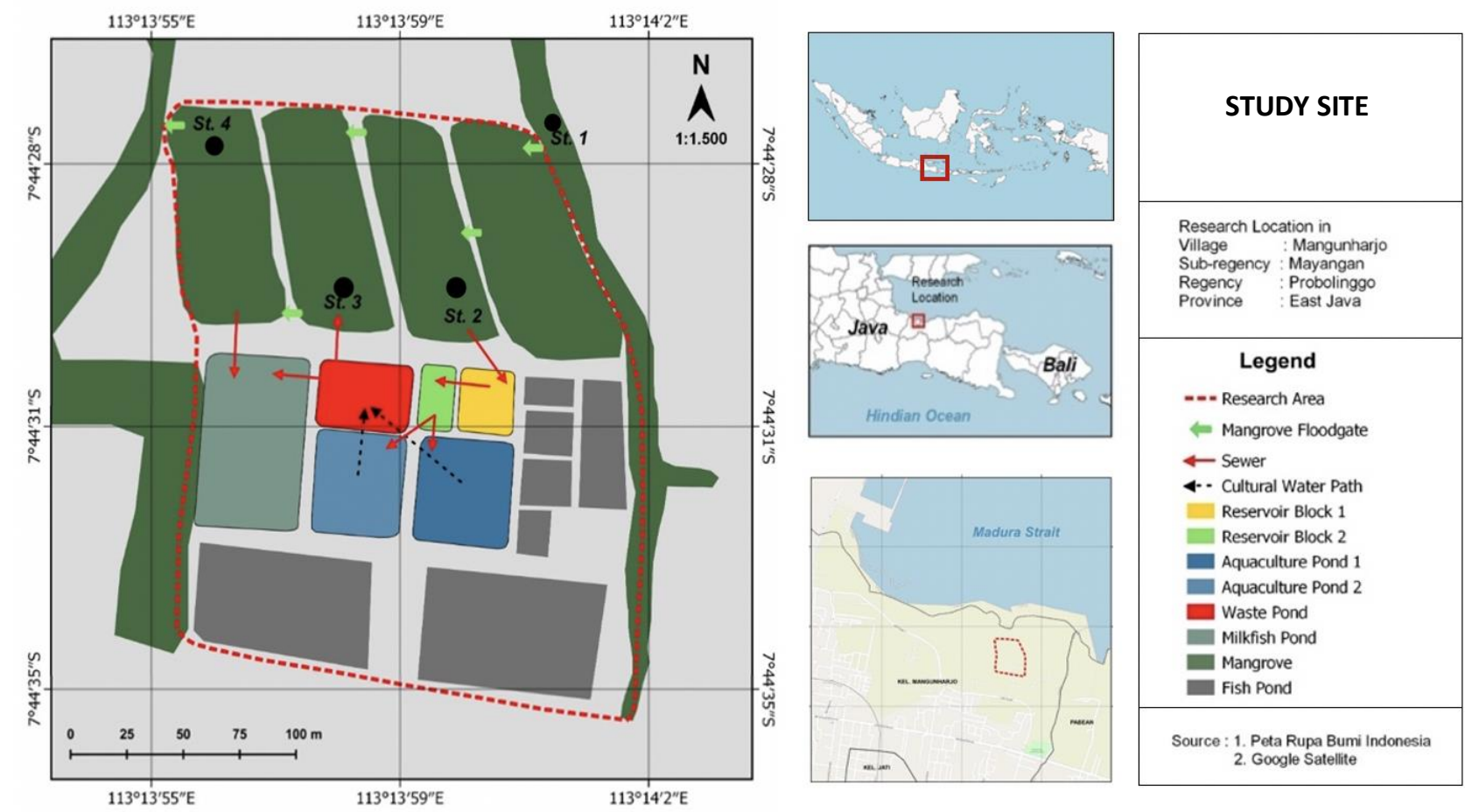

Figure 1. Research area and sampling sites in Brackish and Marine Water Laboratory of Brawijaya University, at Probolinggo District, East Java, Indonesia 


\section{Data analysis}

The effectiveness of the silvofishery system in treating water entering and leaving the intensive pond was analyzed through repeated measurement analysis of variance (ANOVA) because the samples were taken in the same sampling sites but in different time intervals. We also used post-hoc multiple comparison (Tukey) tests for each water quality parameter. We measured the contribution of the mangrove area in treating water from the river by comparing the conditions of the water in Site 1 and Site 2. Meanwhile, the wastewater conditions discharged into adjacent systems from Site 4 was compared with the water quality in Site 3. The biodiversity of the phytoplankton community was calculated using the Shannon-Wiener $\left(\mathrm{H}^{\prime}\right)$ diversity index. These data analyses and calculations were performed using R software.

\section{RESULTS AND DISCUSSION}

\section{Physicochemical water quality parameters}

The results of physicochemical water quality factor analysis in the intensive pond observed in this study are presented in Figure 2. This figure demonstrates that the water temperature was relatively constant across all sites at around $30^{\circ} \mathrm{C}$, and salinity was $20 \%$. Meanwhile, $\mathrm{pH}$ and DO values were below 8 and $7.5 \mathrm{mg} . \mathrm{L}^{-1}$, respectively. These parameters displayed their highest values at Site 1 and lowest at Site 4 (the effluent), except for the salinity in Site 2. The appropriate temperature for white leg shrimp farming is considered to be within the range of 24 to $32^{\circ} \mathrm{C}$. Lower temperatures may decrease the growth potential of the shrimp (Maicá et al. 2014). Moreover, previous studies have revealed that shrimp exhibit their highest food consumption rates at $35^{\circ} \mathrm{C}$ (Ravuru and Mude 2014). Meanwhile, salinity fluctuation in intensive culture may lead to major stress, slow growth, and low survival rates of whiteleg shrimp (Gao et al. 2016). A salinity of $20 \%$ is recommended for optimum growth and survival rates (Su et al. 2010).

Additionally, the suitable $\mathrm{pH}$ range for shrimp cultivation lies between 7.5 and 8.5 (Kasnir 2014; Chatla et al. 2017). In aquatic environments such as shrimp ponds, $\mathrm{pH}$ value is determined by processes of photosynthesis and respiration. The removal of carbon dioxide through photosynthetic processes decreases carbonic acid concentrations, which results in $\mathrm{pH}$ increases, while carbon dioxide released by shrimp during respiration is utilized by phytoplankton for their photosynthetic processes, which create oxygen as a by-product (Shaari et al. 2011). Maintaining dissolved oxygen levels in shrimp ponds is important for shrimp growth and survival. Some studies have found that dissolved oxygen (DO) plays an important role in improving water quality (Boyd 2017; Rahmawati et al. 2020). Notably, the standard minimum for optimal shrimp growth and survival is $3 \mathrm{mg} . \mathrm{L}^{-1}$ (Widanarni et al. 2010).

This study found that the ammonia concentration in the shrimp ponds was between 0.02 and $0.03 \mathrm{mg} . \mathrm{L}^{-1}$, while TOM was below $15 \mathrm{mg} . \mathrm{L}^{-1}$. Ammonia is a toxic form of inorganic nitrogen that is produced in ponds. It originates from the mineralization of organic matter by heterotrophic bacteria. Most aquatic organisms also create it as a byproduct of nitrogen metabolism (Cheng et al. 2017). Concentrations of ammonia in unpolluted water should be under $0.2 \mathrm{mg} . \mathrm{L}^{-1}$ to ensure the healthy growth of fish ( $\mathrm{Lu}$ et al. 2016).
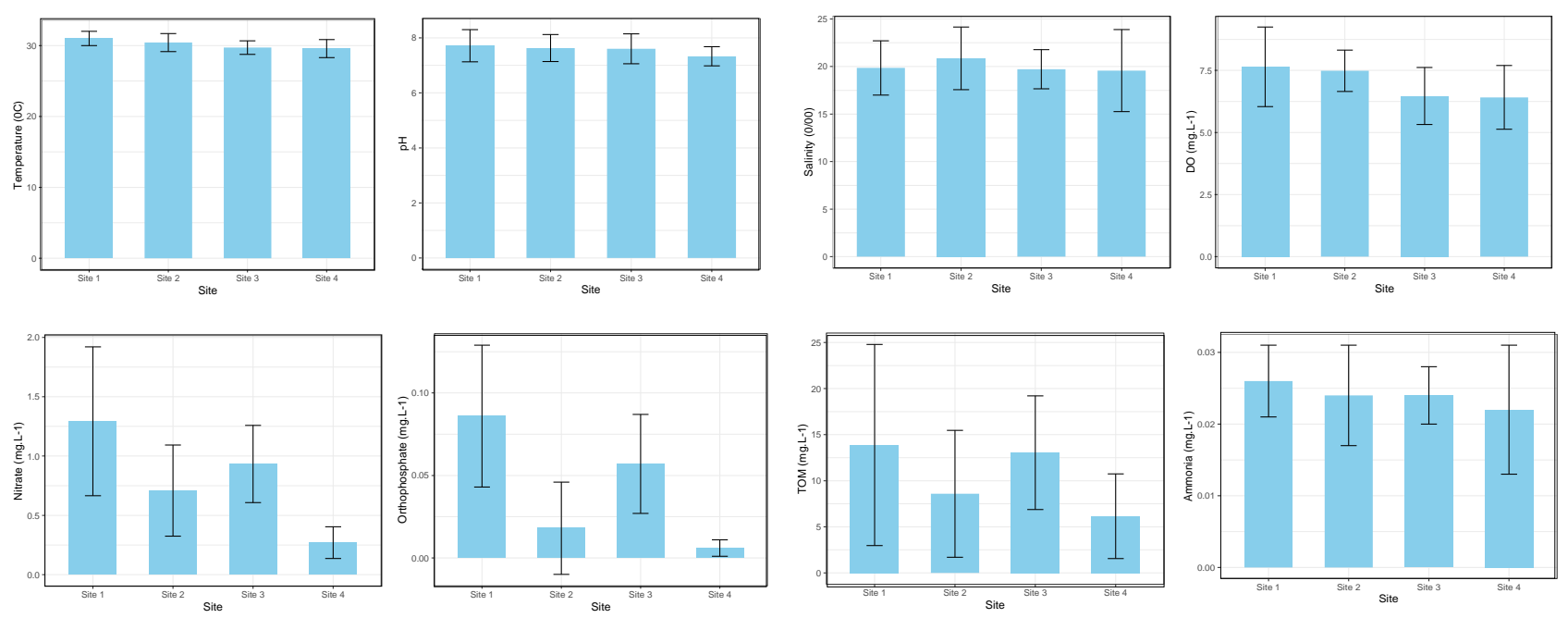

Figure 2. Measurement result of physicochemical water quality parameter 
Nitrate and orthophosphate are major components for primary productivity in an aquatic environment. In an intensive pond system, both compounds are increased by the use of commercial feeds, as natural food production is limited (Dauda et al. 2019). Shrimp farmers impose feed onto their shrimp in a targeted response to shorter harvest periods. This can cause overfeeding and water pollution (Chaikaew et al. 2019). Nutrient concentrations in this study ranged from 0.20 to $1.25 \mathrm{mg} . \mathrm{L}^{-1}$ for nitrate and 0.01 to $0.08 \mathrm{mg} . \mathrm{L}^{-1}$ for orthophosphate.

\section{Diversity and structure of phytoplankton community}

The following Figure 3 depicts the phytoplankton abundance as well as the diversity index $\left(\mathrm{H}^{\prime}\right)$ in each site. Meanwhile, Table 1 exhibits the composition of phytoplankton genera in the studied site.

A total of 32 genera were identified, dominated by genera from the Chrysophyta and Cyanophyta divisions. Site 1 demonstrated the smallest biomass and number of genera but interestingly possessed the highest diversity index. It is because the abundance of each division was relatively equal (Hamilton 2005). Site 2, which contained water used for shrimp cultivation, showed a higher abundance of phytoplankton than Site 1. Moreover, the phytoplankton number of genera in Site 2 was higher than in Site 1, with genera from the divisions Chlorophyta (Eucapsis) and Chrysophyta (Tetraedriella, Cymbella, Cyclotella, Coconeis) present. The abundance of phytoplankton then decreased in Site 3, which had the lowest diversity index. Meanwhile, Site 4 had the largest phytoplankton biomass and displayed a similar diversity index value to Site 2 .

Many previous studies have suggested that mangrove ecosystems are rich in nutrients and thus contribute to the assemblage of phytoplankton along with other physicochemical parameters (Saifullah et al. 2016; Inyang and Wang 2020). This study showed an association between high nutrient concentration and low phytoplankton biomass in Sites 1 and 3. This issue might be a result of other physicochemical parameters such as water transparency, which was not measured in this study. Mangroves also act as sinks for pollutants and traps for land-originated litter (Maiti and Chowdhury 2013; Martin et al. 2019). Hence, they can raise water transparency levels and support phytoplankton production (Dembowska et al. 2018).

Site 3, which contained wastewater from shrimp cultivation, displayed the lowest diversity index. This indicates high levels of pollution in this site that upsets the ecosystem's balance (Inyang and Wang 2020). As a result, the pollutants give rise to the dominance of a specific organism (Al-Hashmi et al. 2013). The existence of mangrove trees in Site 4 successfully increased the diversity of phytoplankton genera as well as their abundance.

\section{Effectiveness of silvofishery system}

The following Figure 4 depicts the results of ANOVA for physicochemical equality across the sites, which are described in box plots.
Table 1. Phytoplankton community structure at intensive whiteleg shrimp ponds in Probolinggo District, East Java, Indonesia

\begin{tabular}{|c|c|c|c|c|}
\hline Division, Genus & Site 1 & Site 2 & Site 3 & Site 4 \\
\hline \multicolumn{5}{|l|}{ Chlorophyta } \\
\hline Ankistrodesmus & + & + & + & + \\
\hline Chlorella & + & + & + & + \\
\hline Chlorogonium & - & - & + & - \\
\hline Cosmarium & + & + & + & + \\
\hline Dysmorphococcus & + & + & + & + \\
\hline Eucapsis & - & + & - & + \\
\hline Kirchneriella & + & + & - & + \\
\hline Pediastrum & - & - & - & + \\
\hline Polytoma & + & + & + & + \\
\hline Scenedesmus & + & + & + & + \\
\hline Schroederia & + & + & + & + \\
\hline Staurastrum & - & - & + & - \\
\hline Tribonema & - & - & + & + \\
\hline Triploceras & - & - & + & + \\
\hline Ulothrix & + & + & + & + \\
\hline \multicolumn{5}{|l|}{ Chrysophyta } \\
\hline Amphora & + & + & + & - \\
\hline Chlorobotrys & + & + & + & + \\
\hline Coconeis & - & + & + & - \\
\hline Cyclotella & - & + & + & - \\
\hline Cymbella & - & + & + & - \\
\hline Navicula & + & + & + & + \\
\hline Nitzschia & + & + & + & + \\
\hline Surirella & + & + & - & + \\
\hline Tetraedriella & - & + & + & + \\
\hline \multicolumn{5}{|l|}{ Euglenophyta } \\
\hline Euglena & + & + & + & + \\
\hline Trachelomonas & + & + & + & + \\
\hline
\end{tabular}

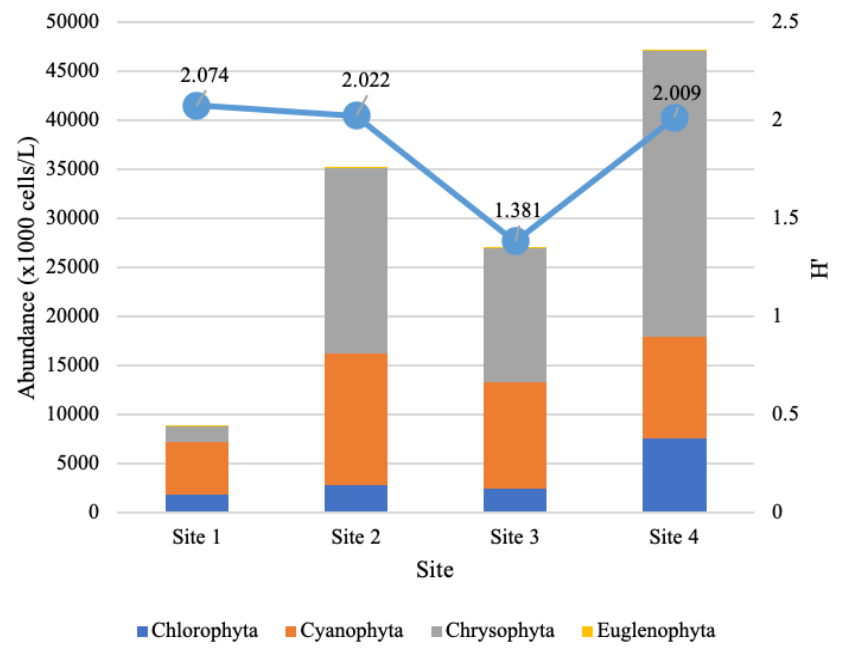

Figure 3. The abundance of phytoplankton and the diversity index $\left(\mathrm{H}^{\prime}\right)$ 

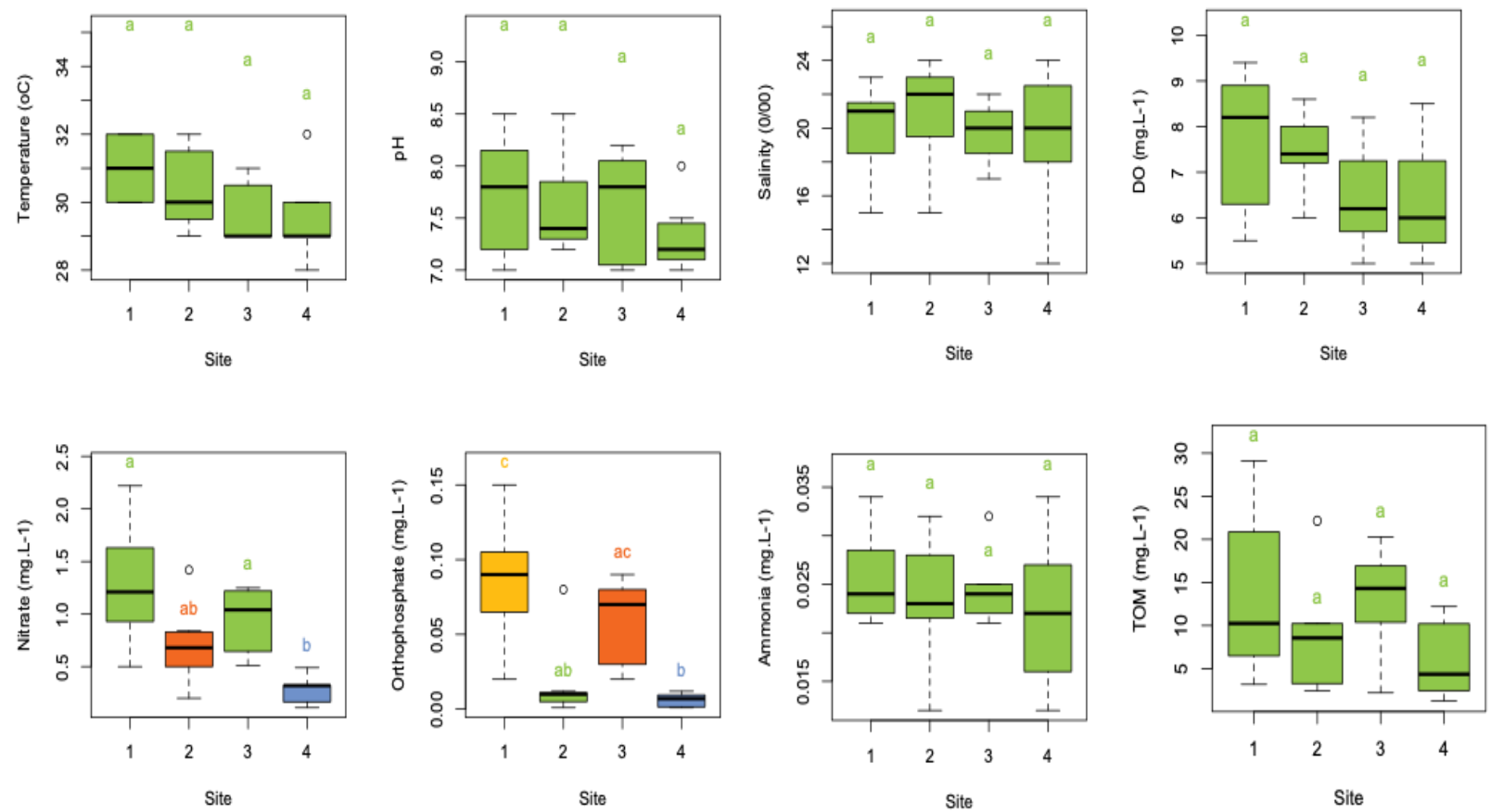

Figure 4. Box-plot (ANOVA) of physicochemical water quality equality across sites

Nutrient concentrations (nitrate and phosphate) were significantly different across sites. The Tukey test revealed that nitrate concentrations in Site 1 and Site 2 were equal but were different from Site 3 and Site 4. Additionally, the phosphate comparisons from Site 1 to Site 2 and Site 3 to Site 4 were statistically different as well. Meanwhile, any box plots that contain a single color indicate that there was not sufficient evidence to conclude physicochemical parameters between sites were different. This study demonstrated no significant difference across all sites in terms of temperature, $\mathrm{pH}$, salinity, DO, and ammonia. However, Figure 3 shows that Site 2 and Site 4 displayed notably lower concentrations of ammonia and TOM than Site 1 and Site 3.

Ammonia accumulation in aquaculture may create toxic environments for cultured shrimp. Moreover, high concentrations of ammonia can lead to survival rate reduction ( $\mathrm{Hu}$ et al. 2012). On the other hand, organic matter may damage aquatic ecosystems because it can create nutrient enrichment that causes algal blooms or eutrophication (Anderson et al. 2012) that can harm environments and threaten other aquatic organisms as well as human health (Berdalet et al. 2015). Therefore, the silvofishery system used in this study was proven to be effective in preventing nutrient enrichment as well as reducing ammonia in cultured ponds and wastewater. Mangroves provide sinks for inorganic and organic nutrients, which can mitigate anthropogenic pollution, control the production in adjacent systems, and ultimately prevent eutrophication (Kaiser et al. 2015).

Finally, the integration of mangroves and aquaculture ponds, known as a silvofishery system, can be used to treat water in an intensive whiteleg shrimp farming system. The application of this system in a shrimp pond in Probolinggo District, East Java, Indonesia revealed that the presence of mangroves was effective at raising the phytoplankton diversity index and quality of water in shrimp farming as well as the wastewater discharged into adjacent waters. Nutrient concentrations were significantly reduced in this system. Other parameters such as TOM and ammonia also decreased, though this was not statistically proven.

\section{ACKNOWLEDGEMENTS}

We want to express our gratitude to Maftuch and Agus Saiful Huda for their help in technical matters at Brackish and Marine Water Laboratory of Brawijaya University during this research. This research received funding from PNBP Brawijaya University through Associate Professor Grant, 2020.

\section{REFERENCES}

Al-Hashmi K, Al-Azri A, Claereboudt MR, Piontkovski S, Amin SMN. 2013. Phytoplankton community structure of a mangrove habitat in the arid environment of Oman: The dominance of Peridinium quinquecorne. J Fish Aquatic Sci 8 (8): 595-606. DOI: $10.3923 /$ jfas.2013.595.606

Anderson DM, Cembella AD, Hallegraeff GM. 2012. Progress in understanding harmful algal blooms: Paradigm shifts and new technologies for research, monitoring, and management. Ann Rev Mar Sci 4: 143-176. DOI: 10.1146/annurev-marine-120308-081121

Anras L, Boglione C, Cataudella S, Dinis MT, Livi S, Makridis P, Marino G, Ramalho A, Yúfera M. 2010. The current status of extensive and semi-intensive aquaculture practices in Southern Europe. Aquac Eur 35 (2): 12-16. 
Barraza-Guardado RH, Arreola-Lizárraga JA, López-Torres MA, CasillasHernández R, Miranda-Baeza A, Magallón-Barrajas F, Ibarra-Gámez C. 2013. Effluents of shrimp farms and its influence on the coastal ecosystems of Bahía de Kino, Mexico. Sci World J 2013: 306370. DOI: $10.1155 / 2013 / 306370$

Berdalet E, Fleming LE, Gowen R, Davidson K, Hess P, Backer LC, Moore SK, Hoagland P, Enevoldsen H. 2015. Marine harmful algal blooms, human health and wellbeing: Challenges and opportunities in the 21st century. J Mar Biol Assoc UK 96 (1): 61-91. DOI 10.1017/S0025315415001733.

Boyd CE. 2017. Chapter 6-General Relationship Between Water Quality and Aquaculture Performance in Ponds. In: Jeney GBT-FD (eds). Fish Diseases. Academic Press, United States.

Chaikaew P, Rugkarn N, Pongpipatwattana V, Kanokkantapong V. 2019. Enhancing ecological-economic efficiency of intensive shrimp farm through in-out nutrient budget and feed conversion ratio. Sustain Environ Res 1: 1-11. DOI: 10.1186/s42834-019-0029-0

Chatla D, Suneetha K, Kavitha K, Govinda R V. 2017. Water quality assessment of pacific white shrimp (Litopenaeus vannamei) in semiintensive culture systems at villages of Prakasam District, Andhra Pradesh, India. Int J Adv Sci Res 2 (4): 123-129.

Cheng Q, Nengzi L, Bao L, Wang Y, Yang J, Zhang J. 2017. Interactions between ammonia, iron and manganese removal using pilot-scale biofilters. J Water Supply: Res Technol-Aqua 66 (3): 157165. DOI: 10.2166/aqua.2017.089

Dauda AB, Ajadi A, Tola-Fabunmi AS, Akinwole AO. 2019. Waste production in aquaculture: Sources, components and managements in different culture systems. Aquac Fish 4 (3): 81-88. DOI: 10.1016/j.aaf.2018.10.002

De-León-Herrera R, Flores-Verdugo F, Flores-de-Santiago F, GonzálezFarías F. 2015. Nutrient removal in a closed silvofishery system using three mangrove species (Avicennia germinans, Laguncularia racemosa, and Rhizophora mangle). Mar Pol Bull 91 (1): 243-248. DOI: $10.1016 /$ j.marpolbul.2014.11.040

Dembowska EA, Mieszczankin T, Napiórkowski P. 2018. Changes of the phytoplankton community as symptoms of deterioration of water quality in a shallow lake. Environ Monitoring Assess 190: 95. DOI: 10.1007/s10661-018-6465-1

Ferreira NC, Bonetti C, Seiffert WQ. 2011. Hydrological and Water Quality Indices as management tools in marine shrimp culture. Aquac 318 (3-4): 425-433. DOI: 10.1016/j.aquaculture.2011.05.045

Gao W, Tian L, Huang T, Yao M, Hu W, Xu Q. 2016. Effect of salinity on the growth performance, osmolarity and metabolism-related gene expression in white shrimp Litopenaeus vannamei. Aquac Rep 4: 125 129. DOI: $10.1016 /$ j.aqrep.2016.09.001

Hamilton AJ. 2005. Species diversity or biodiversity? J Environ Manag 75 (1): 89-92. DOI: 10.1016/j.jenvman.2004.11.012

Herbeck LS, Unger D, Wu Y, Jennerjahn TC. 2013. Effluent, nutrient and organic matter export from shrimp and fish ponds causing eutrophication in coastal and back-reef waters of NE Hainan, tropical China. Continental Shelf Res 57: 92-104. DOI: 10.1016/j.csr.2012.05.006

Hu Z, Lee JW, Chandran K, Kim S, Khanal SK. 2012. Nitrous oxide (N2O) emission from aquaculture: A Review. Environ Sci Technol 46 (12): 6470-6480. DOI: 10.1021/es300110x

Inyang AI, Wang YS. 2020. Phytoplankton diversity and community responses to physicochemical variables in mangrove zones of Guangzhou Province, China. Ecotoxicol 29: 650-668.

Jannah R, Muchlisin ZA, Fmipa B, Syiah U, Aceh B, Perairan JB, Perikanan K, Syiah U, Banda K, Aceh P, Metode B. 2012. Komunita fitoplankton di daerah estuaria Krueng Aceh, Kota Banda Aceh. Depik 1 (3): 189-195. [Indonesia]

Kaiser D, Kowalski N, Böttcher ME, Yan B, Unger D. 2015. Benthic nutrient fluxes from mangrove sediments of an anthropogenically impacted estuary in Southern China. J Mar Sci Eng 3 (2): 466-491. DOI: $10.3390 /$ jmse3020466

Kasnir M. 2014. Water quality parameter analysis for the feasibility of shrimp culture in Takalar District, Indonesia. J Aquac Res Develop 5: 6. DOI: $10.4172 / 2155-9546.1000273$

Krummenauer D, Peixoto S, Cavalli RO, Poersch LH, Wasielesky Jr W. 2011. Superintensive culture of white shrimp, Litopenaeus vannamei, in a biofloc technology system in Southern Brazil at different stocking densities. J World Aquac Soc 42 (5): 726-733. DOI: 10.1111/j.17497345.2011.00507.x
López BD. 2011. Aquaculture systems. In: Handbook of Ecological Models used in Ecosystem and Environmental Management. Taylor \& Francis Group, USA.

Lu X, Kong J, Luan S, Dai P, Meng X, Cao B, Luo K. 2016. Transcriptome analysis of the hepatopancreas in the pacific white shrimp (Litopenaeus vannamei) under acute ammonia stress. PLoS ONE 11 (10): e0164396. DOI: 10.1371/ journal.pone.0164396

Mahmudi M, Lusiana ED, Herawati EY, Serihollo LG. 2020 Environmental factors and seasonal effect on the potential harmful algae presence at Ambon Bay, Indonesia. Biodiversitas 21 (7): 3101 3107. DOI: $10.13057 /$ biodiv/d210730

Maicá PF, de Borba MR, Martins TG, Wasielesky W. 2014. Effect of salinity on performance and body composition of Pacific white shrimp juveniles reared in a super-intensive system. R Bras Zootec 43 (7): 343-350. DOI: 10.1590/S1516-35982014000700001

Maiti SK, Chowdhury A. 2013. Effects of anthropogenic pollution on mangrove biodiversity: A review. J Environ Prot 4 (12): 1428-1434.

Martin C, Almahasheer H, Duarte CM. 2019. Mangrove forests as traps for marine litter. Environ Poll 247: 499-508. DOI: 10.1016/j.envpol.2019.01.067

Na-nakorn A, Chevakidagarn P, Danteravanich S. 2017. Environmental impact of white shrimp culture during 2012-2013 at Bandon Bay, Surat Thani Province: A case study investigating farm size. Agric Nat Resour 51 (2): 109-116. DOI: 10.1016/j.anres.2016.08.007

Nguyen KAT, Nguyen TAT, Jolly C, Nguelifack BM. 2020. Economic efficiency of extensive and intensive shrimp production under conditions of disease and natural disaster risks in Khánh Hòa and Trà Vinh provinces, Vietnam. Sustainability 12 (5): 2140. DOI: $10.3390 / \mathrm{su} 12052140$

Nguyen TAT, Nguyen KAT, Jolly C. 2019. Is super-intensification the solution to shrimp production and export sustainability? Sustainability 11 (9): 5277. DOI: 10.3390/su11195277.

Nguyen TTH, Ford A. 2010. Learning from the neighbors: Economic and environmental impacts from intensive shrimp farming in the mekong delta of Vietnam. Sustainability 2 (7): 2144-2162. DOI: $10.3390 / \mathrm{su} 2072144$

Oddsson GV. 2020. A definition of aquaculture intensity based on production functions-the aquaculture production intensity scale (APIS). Water 12 (3): 765. DOI: 10.3390/w12030765

Ouyang X, Guo F. 2016. Paradigms of mangroves in treatment of anthropogenic wastewater pollution. Sci Total Environ 544: 971-979. DOI: $10.1016 /$ j.scitotenv.2015.12.013

Rahmawati AI, Saputra RN, Hidayatullah A, Dwiarto A, Junaedi H, Cahyadi D, Saputra HKH, Prabowo WT, Kartamiharja UKA, Shafira H, Noviyanto A, Rochman NT. 2020. Enhancement of Penaeus vannamei shrimp growth using nanobubble in indoor raceway pond. Aquac Fish. DOI: 10.1016/j.aaf.2020.03.005

Ravuru DB, Mude JN. 2014. Effect of density on growth and production of Litopenaeus vannamei of brackish water culture system in summer season with artificial diet in Prakasam District, India. Am Int J Res Form Appl Nat Sci 5 (1): 10-13.

Saifullah ASM, Kamal AHM, Idris MH, Rajaee AH, Bhuiyan MKA. 2016. Phytoplankton in tropical mangrove estuaries: role and interdependency. For Sci Technol 12: 104-113. DOI: 10.1080/21580103.2015.1077479

Samadan GM, Rustadi, Djumanto, Murwantoko. 2018. Production performance of whiteleg shrimp Litopenaeus vannamei at different stocking densities reared in sand ponds using plastic mulch. AACL Bioflux 11 (4): 1213-1221.

Sari M, Hatta M, Permana A. 2014. Ecological status and development of silvofishery for increasing peoples economy (The Case of RPH-Tegal Tangkil, KPH Purwakarta, Blanakan Subang East Java). Acta Aquatica 2 (1): 41-47.

Setiadi E, Setijaningsih L. 2011. Improving water quality and productivity of tilapia (Oreochromis niloticus) using constructed wetland. Indon Aquac J 6 (2): 107-122. DOI: 10.15578/iaj.6.2.2011.107-122

Shaari AL, Surif M, Latiff FA, Omar WMW, Ahmad MN. 2011. Monitoring of water quality and microalgae species composition of Penaeus monodon ponds in Pulau Pinang, Malaysia. Trop Life Sci Res 22 (1): 51-69.

Sitompul TK, Sahara S, Anggraeni L. 2018. The effects of trade facilitation on indonesian fisheries export. Jurnal Manajemen dan Agribisnis 15 (3): 230-238. DOI: 10.17358/jma.15.3.230

Su Y, Feng C, Ma S. 2010. Effects of salinity fluctuation on the growth and energy budget of juvenile Litopenaeus vannamei at different 
temperatures. J Crustacean Biol 30 (3): 430-434. DOI: 10.1651/093269.1

Thakur K, Patanasatienkul T, Laurin E, Vanderstichel R, Corsin F, Hammell L. 2018. Production characteristics of intensive whiteleg shrimp (Litopenaeus vannamei) farming in four Vietnam Provinces. Aquac Res 49 (8): 2625-2632. DOI: 10.1111/are.13720

Tian Y, Chen G, Tang F, Zheng C, Ye Y. 2018. Effects of different types of nutrient effluent from shrimp ponds on the seedling growth of Kandelia obovata. Acta Oceanologica Sinica 37 (6): 112-120. DOI: $10.1007 / \mathrm{s} 13131-018-1207-3$
Venkateswarlu V, Seshaiah P, Arun P, Behra P. 2019. A study on water quality parameters in shrimp L. vannamei semi-intensive grow out culture farms in coastal districts of Andhra Pradesh, India. Int J Fish Aquatic Stud 7 (4): 394-399.

Widanarni, Yuniasari D, Sukenda, Ekasari J. 2010. Nursery culture performance of Litopenaeus vannamei with probiotics addition and different $\mathrm{C} / \mathrm{N}$ ratio under laboratory condition. Hayati J Biosci 17 (3): 115-119. DOI: $10.4308 / \mathrm{hjb}$.17.3.115. 